\title{
Effectiveness of interactive teaching intervention on medical students' knowledge and attitudes toward stem cells, their therapeutic uses, and potential research applications
}

\author{
Fayez Abdulrazeq ${ }^{1}$, Khalid A. Kheirallah ${ }^{\text {Corresp., } 1}$, Abdel-Hameed Al-Mistarehi ${ }^{\text {Corresp., } 1}{ }^{2}$, Samir Al Bashir ${ }^{2}$, Mohammad \\ Alqudah $^{2}$, Abdallah Alzoubi ${ }^{3,4}$, Jomana Alsulaiman ${ }^{5}$, Mazhar S. Al Zoubi ${ }^{6}$, Abdulwahab Al-Maamari ${ }^{7}$ \\ ${ }^{1}$ Department of Public Health and Family Medicine, Faculty of Medicine, Jordan University of Science and Technology, Irbid, Jordan \\ 2 Department of Pathology and Microbiology, Faculty of Medicine, Jordan University of Science and Technology, Irbid, Jordan \\ 3 College of Medicine, Ajman University of Science \& Technology, Ajman, United Arab Emirates \\ 4 Department of Pharmacology, Faculty of Medicine, Jordan University of Science and Technology, Irbid, Jordan \\ 5 Department of Pediatrics, Faculty of Medicine, Yarmouk University, Irbid, Jordan \\ 6 Department of Basic Medical Sciences, Faculty of Medicine, Yarmouk University, Irbid, Jordan \\ 7 Department of Private Law, Faculty of Law, Al-Isra Private University, Amman, Jordan \\ Corresponding Authors: Khalid A. Kheirallah, Abdel-Hameed Al-Mistarehi \\ Email address: kakheirallah@just.edu.jo, awalmistarehi18@med.just.edu.jo
}

Background: Stem cell science is rapidly developing with potential use to alleviate many non-treatable diseases. Medical students, as future physicians, should be equipped with the proper knowledge and attitude regarding this hopeful field. Interactive teaching whereby the teachers actively involve the students in the learning process is a promising approach to improve their interest, knowledge, and team spirit. This study aims to evaluate the effectiveness of an interactive teaching intervention on medical students' knowledge and attitudes about stem cell research and therapy.

Methods: A pre-post test study design was employed. A six-session interactive teaching course was conducted for a duration of six weeks as an intervention. Pre- and post-intervention surveys were used. The differences in the mean scores of students' knowledge and attitudes were examined using paired ttest, while gender differences were examined using an independent t-test.

Results: Out of 71 sixth-year medical students from different nationalities invited to participate in this study, the interactive teaching course was initiated by 58 students resulting in a participation rate of $81.7 \%$. Out of 58 students, $48(82.8 \%)$ completed the entire course. The mean age (standard deviation) of students was 24 (1.2) years, and $32(66.7 \%)$ were males. The results showed poor knowledge about stem cells among the medical students in the pre-intervention phase. Total scores of stem cell-related knowledge and attitudes significantly improved post-intervention. Gender differences in knowledge and attitudes scores were not statistically significant post-intervention.

Conclusions: Integrating stem cell science into medical curricula coupled with interactive learning approaches effectively increased students' knowledge about recent advances in stem cell research and therapy and improved attitudes toward stem cell research and applications. 
Title Page

\section{Effectiveness of interactive teaching intervention on medical students' knowledge and attitudes toward stem cells, their therapeutic uses, and potential research applications}

Running title: Stem cell-related education intervention

Fayez Abdulrazeq ${ }^{1}$, Khalid A. Kheirallah ${ }^{1 *}$, Abdel-Hameed Al-Mistarehi ${ }^{*}$, Samir Al Bashir ${ }^{2}$, Mohammad A. AlQudah ${ }^{2}$, Abdallah Alzoubi ${ }^{3,4}$, Jomana Alsulaiman ${ }^{5}$, Mazhar S. Al Zoubi ${ }^{6}$, Abdulwahab Al-Maamari ${ }^{7}$

1- Department of Public Health and Family Medicine, Faculty of Medicine, Jordan University of Science and Technology, Irbid, Jordan.

2- Department of Pathology and Microbiology, Faculty of Medicine, Jordan University of Science and Technology, Irbid, Jordan.

3- Department of Pharmacology, Faculty of Medicine, Jordan University of Science and Technology, Irbid, Jordan.

4- College of Medicine, Ajman University, Ajman, United Arab Emirates.

5- Department of Pediatrics, Faculty of Medicine, Yarmouk University, Irbid, Jordan.

6- Department of Basic Medical Sciences, Faculty of Medicine, Yarmouk University, Irbid Jordan.

7- Department of Private Law, Faculty of Law, Isra University, Amman, Jordan.

\section{List of Authors:}

\begin{tabular}{|c|c|c|c|c|}
\hline Order & Position & $\begin{array}{c}\text { First (given) } \\
\text { name }\end{array}$ & $\begin{array}{c}\text { Last (family) } \\
\text { name }\end{array}$ & Email \\
\hline $1^{\text {st }}$ & Lecturer & Fayez & Abdulrazeq & Faabdulrazeq16@,med.just.edu.jo \\
\hline $2^{\text {nd }}$ & Associate Professor & Khalid A. & Kheirallah & kakheirallah@just.edu.jo \\
\hline $3^{\text {rd }}$ & M.D. & Abdel-Hameed & Al-Mistarehi & $\underline{\text { dr.abedhwm@yahoo.com }}$ \\
\hline $4^{\text {th }}$ & Associate Professor & Samir M. & Al Bashir & $\underline{\text { smalbashir9@,just.edu.jo }}$ \\
\hline $5^{\text {th }}$ & Associate Professor & Mohammad A. & Al-Qudah & $\underline{\text { m.alqudah12@,just.edu.jo }}$ \\
\hline $6^{\text {th }}$ & Associate Professor & Abdallah & Alzoubi & $\underline{\text { aaalzoubi28@,just.edu.jo }}$ \\
\hline $7^{\text {th }}$ & Assistant Professor & Jomana & Alsulaiman & jomana.a@yu.edu.jo \\
\hline $8^{\text {th }}$ & Associate Professor & Mazhar S. & Al Zoubi & $\underline{\text { mszoubi@yu.edu.jo }}$ \\
\hline $9^{\text {th }}$ & Associate Professor & Abdulwahab & Al-Maamari & almamary3@,hotmail.com \\
\hline
\end{tabular}


25

26

27

28

29

30

31

32

33

34

35

36

37

38

39

40

41

42

43

44

45

46

47

48

49

50

51

52

53

54

55

56

57
*Corresponding Authors:

\section{Abdel-Hameed Al-Mistarehi}

M.D.,

Department of Public Health and Family Medicine, Faculty of Medicine,

Jordan University of Science and Technology

P.O.Box 3030, Irbid 22110, Jordan

Email: dr.abedhwm@yahoo.com

Phone number: +962798284360

\section{Khalid A. Kheirallah}

Associate Professor,

Department of Public Health and Family Medicine, Faculty of Medicine,

Jordan University of Science and Technology

P.O.Box 3030, Irbid 22110, Jordan

Email: faabdulrazeq16@med.just.edu.jo

Phone number: +962 796119094 
59

60

61

62

63

64

65

66

67

\section{Abstract}

Background: Stem cell science is rapidly developing with potential use to alleviate many nontreatable diseases. Medical students, as future physicians, should be equipped with the proper knowledge and attitude regarding this hopeful field. Interactive teaching whereby the teachers actively involve the students in the learning process is a promising approach to improve their interest, knowledge, and team spirit. This study aims to evaluate the effectiveness of an interactive teaching intervention on medical students' knowledge and attitudes about stem cell research and therapy.

Methods: A pre-post test study design was employed. A six-session interactive teaching course was conducted for a duration of six weeks as an intervention. Pre- and post-intervention surveys were used. The differences in the mean scores of students' knowledge and attitudes were examined using paired t-test, while gender differences were examined using an independent t-test.

Results: Out of 71 sixth-year medical students from different nationalities invited to participate in this study, the interactive teaching course was initiated by 58 students resulting in a participation rate of $81.7 \%$. Out of 58 students, $48(82.8 \%)$ completed the entire course. The mean age (standard deviation) of students was 24 (1.2) years, and $32(66.7 \%)$ were males. The results showed poor knowledge about stem cells among the medical students in the pre-intervention phase. Total scores of stem cell-related knowledge and attitudes significantly improved post-intervention. Gender differences in knowledge and attitudes scores were not statistically significant post-intervention.

Conclusions: Integrating stem cell science into medical curricula coupled with interactive learning approaches effectively increased students' knowledge about recent advances in stem cell research and therapy and improved attitudes toward stem cell research and applications. 
80 Keywords: Stem cells; knowledge; Attitudes; Interactive teaching; Education; Medical curriculum;

81 Students; Jordan; Arab

\section{Introduction}

83

84

85

86

87

88

89

90

91

92

93

94

95

96

97

98

99

100

101

The emerging stem cell (SC) biology discipline and the rapid revolution in SC research have radically transformed our thinking of cells, evolution, and disease. Using SCs for clinical applications represents the future of translational medicine since SCs can potentially be used to treat many kinds of difficult diseases that cannot currently be treated (Chang et al. 2018; Protze et al. 2019). Advances in SC research combined with tissue engineering techniques promise therapies to restore or replace damaged tissues (Kwon et al. 2018). This raises the need for medical education to introduce basic SC knowledge and the concept of translational medicine into the life sciences field. At the same time, SC research and applications still raise complex social, legal, ethical, and religious issues (Al-Aqeel 2005; Curley \& Sharples 2006; Pourebrahim et al. 2020), especially in conservative societies (Bouzenita 2017).

The emerging developments in SC applications are transforming the priorities of undergraduate and postgraduate medical educational programs (Scott 2015). Today, the traditional academic model for medical education is challenged by an evident gap between the rapidly changing disciplines in basic biomedical sciences and clinical practice. Although medical students have access to SC research theoretical advancements, traditional teaching approaches still fail to bridge this practice gap (Brass 2009). Thus, updated teaching techniques that facilitate the integration of SC research advancements with clinical practice are critical for medical students to achieve optimum patient care (Knoepfler 2013). Restructuring medical education to meet the current and future health care needs of SC-based interventions, including new curricula featuring 
102 the ethical, legal, and social implications of SC research, are thus a priority (Pershing \& Fuchs 103 2013; Pierret \& Friedrichsen 2009).

104

105

106

107

108

109

110

111

112

113

114

115

116

117

118

119

120

121

122

123

Since the early 1990s, many medical curricula have transitioned from traditional subjectbased teaching toward integrated system-based teaching (Ling et al. 2008). Traditional didactic lectures for one hour become monotonous after 15-20 minutes as students' participation in the learning process is minimal (Gupta et al. 2015). On the other hand, the interactive teaching approach actively engages learners and interchanges ideas between learners and facilitators (Kaur et al. 2011). The effectiveness of educational interventions in increasing knowledge and attitudes towards SC applications was reported previously by a few studies (Azzazy \& Mohamed 2016; Jin et al. 2018; Kaya et al. 2015).

Although it is currently a hot research topic, SC education for students is uncommon (Pierret \& Friedrichsen 2009). The interactive teaching modality was designed to introduce medical students to the pioneering area of SC biology and shed light on current advances in SC research. Medical students, as future physicians, are expected to answer patients' questions regarding SCs and help them differentiate between what is realistic and unrealistic regarding SCbased therapies. Also, they should be able to use evolving discoveries in SC research and apply them in the care of patients. Thus, we aimed in this study to gauge the medical students' knowledge and attitudes toward SCs, their therapeutic uses, and potential research applications and then evaluate the effectiveness of a six-session interactive teaching intervention on their knowledge and attitudes. 


\section{Study design, participants, and setting:}

125

126

127

128

129

130

131

132

133

134

135

136

137

138

139

140

141

142

143

144

145

A pre-post test design was employed for a sample of 71 sixth-year medical students, at the University of Science and Technology Yemen-Jordan branch (USTY-Jo), during the first semester of the academic year 2018-2019. An orientation lecture was held before the initiation of the study to explain the study aims, design, and details for the students and invite the students to participate. Study participation was voluntary, and the pre-intervention survey was distributed to all medical students who agreed to participate. After that, the participants were then invited to attend a sixsession interactive teaching course, the intervention, for a duration of six weeks. This intervention was a part of phase I of the "Stem Cells: Hope or Hype?" project. Each interactive session lasted two to three hours and included brainstorming, learning by teaching, role-playing, class debate, panel discussions, reflections on stories, real-life situations, case-based scenarios, or videos. Details about the intervention are summarized in Table 1. After finishing the intervention, the same survey was distributed among the participants.

\section{Ethical considerations:}

The study protocol was reviewed and ethically approved by the Institutional Review Board (IRB) of the research and ethics committee at USTY-Jo (IRB number, 9/120/2019). This study was conducted following the 1975 Helsinki declaration, as revised in 2008 and later amendments or comparable ethical standards. The study objectives and design were duly explained to the study participants during the orientation lecture and with each intervention session. They were informed about the study objectives, design, duration, interactive teaching methods, and the guest lecturers were invited to participate in the interactive teaching sessions. A written, signed, informed consent was obtained from each participant. Participants were informed that they could terminate the 
146 survey and interventions at any time desired. Participants did not receive any compensation or

147 rewards for their participation in the study.

To conduct the study with keeping the participant anonymity and survey confidentiality in

light of its pre-post test design, we need a method of identifying the participant so that we can

150

151

152

153

154

155

156

157

158

159

160

161

162

163

164

165

166

167

168

measure the change from the first survey to the second for the same participant without breaching the anonymity and confidentiality. One possible way is to anonymously generate a unique ID code for each participant. The codes should be easily recovered if needed, unlikely duplicated across multiple respondents, and unique for each participant. Thus, a coding system was created based on the participants' names and birth dates. We asked each participant to generate their own ID code by providing the first letters of their first and family names (A-Z) plus a four-digit code that represents birthday (01-31) and month of birth (01-12). The participants' ID codes were essential for data analysis to compare pre-and-post intervention scores and avoid duplicated data with preserving anonymity. Thus, the study was undertaken with complete confidentiality, and information provided by study participants was not disclosed to others.

\section{Study tools:}

After detailed reviewing the literature regarding SC knowledge and attitudes, the researchers developed a structured, self-administered questionnaire. The questionnaire was not based on a particular study but preferably on information from various studies and recent guidelines from international organizations such as the International Society for Stem Cell Research (ISSCR) and the New York Stem Cell Foundation (NYSCF) (Azzazy \& Mohamed 2016; Lovell-Badge et al. 2021; NYSCF 2017). The questionnaire was reviewed by a panel of experts in SC clinical practice and teaching, pilot-tested on 20 participants, and the necessary modifications were done. The questionnaire was designed and distributed in the English language as it is the 
169 official teaching language of the Jordanian medical schools. A soft copy of the distributed 170 questionnaire is provided in supplementary file 1.

173 demographic characteristics, SC knowledge, and SC attitudes. The demographics section included

174 questions about age, gender, nationality of participants, name of the registered medical school, and

175 student year level. The SC knowledge section began with a rating question about the participant

176 perception of knowledge regarding SCs in general with a ten-point Likert scale, ranging from "zero

177 = low knowledge" to " $10=$ high knowledge". Then, a question about the participants' preferred

178 sources of knowledge about SCs with multiple choices included books, medical journals, 179 workshops, social media, lectures, medical conferences, panel discussions, and other sources.

After that, the SC knowledge section included 27 statements to measure the participants'

false or misleading statements, and neither true nor false statements, with a total of nine statements.

The SC knowledge section statements have an acceptable to excellent internal consistency and reliability with a Cronbach's Alpha of 0.61 and 0.78 in pre-and post-intervention, respectively. The SC knowledge section was divided into four domains, including basic knowledge about SCs with a total of 13 statements (Cronbach's Alpha $=0.42$ and 0.61 in pre-and post-intervention, respectively), potential applications of SCs with a total of four statements (Cronbach's Alpha $=0.69$ and 0.66 ), therapeutic uses of SCs with a total of four statements (Cronbach's Alpha $=0.44$ and 0.32 ), and lastly the participant knowledge about SC research with a total of six statements 
191 attitudes toward SCs via a total of ten statements with Cronbach's Alpha of 0.76 and 0.68 in pre-

192 and post-intervention, respectively.

193 Participants responded to each statement of the SC knowledge and attitude scales described 194 above, using a 5-point Likert scale ranging between "Strongly Disagree" and "Strongly Agree" for 195 each statement to provide high-resolution data and detailed information. After that, each response 196 was scored from "Zero = Strongly Disagree" to "Four = Strongly Agree" except for the seven false

197 statements, where the code was reversed to be "Four = Strongly Disagree" and "Zero = Strongly 198 Agree". Responses to statements were summed to create scores for the total knowledge, each of 199 the four knowledge domains, and total attitude. Thus, higher scores indicated good knowledge and 200 positive attitude, while lower scores indicated poor knowledge and negative attitude. Knowledge 201 scores ranged from zero to 108 for "total SC knowledge", zero to 52 for "SC basic knowledge", 202 zero to 16 for "SC potential applications", zero to 16 for "SC therapeutic uses", and zero to 24 for 203 "SC research". The total attitude score ranged from zero to 40. After that, the scores of scales were 204 converted into mean scores ranging from zero to four by dividing the scale score on the number of 205 scale statements. Version 25.0 (IBM Corp., Armonk, NY, USA). Internal consistency for scales and subscales were tested using Cronbach's alpha. Descriptive statistics were presented as means and standard deviations (SD) for continuous variables after verifying the normality of the dataset. Categorical variables were presented as proportions and frequencies. A Paired-samples $t$-test was used to examine the mean differences (MD) in students' knowledge and attitude scores pre- and posteducational intervention, and the statistical significance and $95 \%$ confidence intervals of the 
214 difference in means were reported. Independent-samples $t$-test was used to examine mean gender

215 differences in students' knowledge and attitude scores. A p-value was set at or less than 0.05 to be 216 significant.

217

\section{Results}

Out of 71 sixth-year medical students invited to participate in this study, 58 initiated the interactive teaching course resulting in a participation rate of $81.7 \%$. The final sample consisted of 48 medical students who initially enrolled and completed the entire six-week course sessions with a completion rate of $82.8 \%$. Out of 48 medical students, $32(66.7 \%)$ were males, and more than half $(56.3 \%)$ were of Jordanian or Yemeni nationalities. The enrolled Students' mean age (SD) was 24.0 (1.2) years. Demographic characteristics of study participants are summarized in

Table 2.

\section{Knowledge regarding stem cells}

The three most common sources of knowledge regarding SCs before the intervention course were lectures (56.3\%), social media (45.8\%), and books (41.7\%), while any participant did not report panel discussions as a source of knowledge (Figure 1). Detailed information about preand post-educational intervention knowledge scores is summarized in Table 3. Pre-intervention, the lowest mean score among knowledge domains was observed with SC research section (1.76 (0.89)), and therapeutic uses (1.84 (0.63)), followed by SC basic knowledge $(2.14(0.30))$ and their potential applications $(2.66(0.77))$. The mean scores of all knowledge domains were lower than

234 three in the pre-intervention phase of the study. The mean (SD) total knowledge score was 2.09 
235 (0.30) pre-intervention, which is significantly improved to $3.09(0.41)$ post-intervention $(p<0.001)$.

236 Similarly, all knowledge domains' scores significantly increased following the intervention.

237

238

239

240

241

242

243

244

245

246

247

248

249

250

251

252

253

254

255

256

257

The mean SC basic knowledge domain score significantly increased from 2.14 (0.30) preintervention to $3.09(0.47)$ post-intervention $(p<0.001)$. Post-intervention vs. pre-intervention, participants reported improved the knowledge with different types of SCs $(3.77$ (0.43) vs. 1.88 (0.94), $p<0.001)$, sources of SCs (3.67 (0.52) vs. $2.17(0.78), p<0.001)$, therapeutic uses of SCs (3.69 (0.51) vs. $2.15(1.05), p<0.001)$ and three germ layers from which tissues and organs are generated (3.69 (0.59) vs. $2.67(1.02), p<0.001)$. Students' knowledge of sources of embryonic SCs significantly improved for statements related to leftover blastocysts after in vitro fertilization (2.96 (1.34) post-intervention vs. $2.06(0.76)$ pre-intervention, $p<0.001)$, but not for statements related to umbilical cord $(1.73(1.65)$ vs. $1.35(0.91), p=0.165)$ or trophoblast of blastocyst $(1.79$ (1.64) vs. $1.54(0.65), p=0.316)$.

For potential applications of SC domain, the mean score significantly increased from 2.66 (0.77) pre-intervention to $3.46(0.59)$ post-intervention $(p<0.001)$. Post-intervention vs. preintervention, students reported significantly higher knowledge scores regarding potential applications of SCs such as replacing or restoring damaged tissues (3.58 (0.85) vs. 2.85 (1.09), $p<0.001)$, screening new drugs and toxins (3.48 (0.83) vs. $2.21(1.09), p<0.001)$, modeling disease in a culture dish $(3.48(0.83)$ vs. $2.56(1.09), p<0.001)$ and studying early human development (3.42 (0.71) vs. $3.02(0.84), p=0.004)$.

For SC therapeutic uses domain, the mean total score significantly increased from 1.84 (0.63) pre-intervention to $2.45(0.80)$ after the intervention course $(p<0.001)$. Compared to preintervention results, the students became significantly more aware about the side effects of trying unproven SC therapies after the intervention course $(2.38(1.39)$ vs. $1.71(1.07), p=0.003)$ and 
258 tumor formation potential if the balance is skewed between cell differentiation and self-renewing

259 properties of SCs $(2.88(1.04)$ vs. $2.25(0.79), p=0.001)$.

260 In the SC research domain, the mean total score significantly increased from $1.76(0.89)$ to

$2613.27(0.56)(p<0.001)$. Post-intervention vs. pre-intervention, students became more comfortable

262 in giving an explanation of induced pluripotent SCs $(3.40(0.71)$ vs. $1.65(1.16), p<0.001)$,

263 transcription factors $(3.13(0.89)$ vs. $1.85(1.19), p<0.001)$, and differences between therapeutic

264 cloning and reproductive cloning (3.21 (0.82) vs. $1.81(1.20), p<0.001)$. Moreover, participants

265 became more knowledgeable that adult cells can be "reprogrammed" genetically to assume an SC-

266 like state $(3.31(0.83)$ vs. $1.85(1.05), p<0.001)$. Students were also more comfortable discussing

267 mitochondrial replacement therapy $(3.52(0.74)$ vs. $1.83(1.19), p<0.001)$ and somatic cell nuclear

268 transfer $(3.06(0.10)$ vs. $1.58(1.07), p<0.001)$.

269

270

271

272

273

274

275

276

277

278

279

280

\section{Attitudes toward stem cells}

As described in Table 4, the total attitude score significantly increased from $2.66(0.56)$ to $2.85(0.53)(p=0.048)$. Post-intervention vs. pre-intervention, students became more interested in expanding their knowledge regarding SCs (3.77 (0.43) vs. 3.29 (0.92), $p=0.001)$, and considered a well-structured program or training focusing on SC science (3.48 (0.68) vs. 2.83 (0.91), $p<0.001)$. Students reported improved positive attitudes regarding integration of SC education in medical college curricula $(3.35(0.93)$ vs. $2.83(0.10), p=0.010)$, translational research $(3.27(0.84)$ vs. $2.83(0.93), p=0.009)$, and spending more money by government to support SC research (3.69 (0.72) vs. $3.38(0.82), p=0.046)$. In addition, participants' improvements in attitude were statistically significant towards umbilical cord blood donation (3.27 (1.13) vs. 2.85 (0.10), $p=0.049)$, but not for bone marrow donation $(3.10$ (1.23) vs. $2.81(0.94), p=0.212)$. Participants' negative attitudes regarding religious controversies surrounding SCs did not improve as the pre-

Peer] reviewing PDF | (2021:10:66942:1:0:NEW 26 Dec 2021) 
281 intervention mean significantly decreased from $1.88(1.10)$ to $1.13(1.30),(p=0.003)$. However,

282 similar reductions reported in attitude mean scores related to ethical controversies surrounding SCs

$283(1.13(1.20)$ post-intervention vs. $1.29(1.09)$ pre-intervention, $p=0.420)$ and preserving umbilical

284 cord blood in a private bank (2.35 (1.52) post-intervention vs. 2.63 (1.20) pre-intervention, $285 p=0.322)$ but they were not statistically significant.

$286 \quad$ Gender Differences

As shown in Table 5, male students at baseline scored higher knowledge levels in

(0.85) respectively, $p=0.014)$ and $\mathrm{SC}$ research $(1.95(0.81)$ vs. $1.39(0.95)$ respectively, $p=0.036)$.

290

291

292

293

294

295

296

297

298

299

300

301

302

Accordingly, the total knowledge score of males was higher than females $(2.16(0.27)$ vs. 1.95

(0.30) respectively, $p=0.017)$. However, after the intervention, gender differences were not statistically significant.

\section{Discussion}

The current study sheds light on the effectiveness of an interactive educational intervention in improving the knowledge and attitudes of medical students toward SCs, their therapeutic uses, and their potential research applications. The intervention course was conducted for six weeks, and different interactive teaching methods were used. The study results indicated that participants' knowledge about SCs was insufficient in the pre-intervention phase as the mean scores for most knowledge domains and total knowledge were $\leq 2$. These findings are concordant with previous studies that revealed poor knowledge regarding various aspects of stem cells banking, donation, and transplantation among the public, university students, and healthcare providers (Azzazy \& 
303 Mohamed 2016; Kaya et al. 2015; Lye et al. 2015; Perlow 2006; SUEN et al. 2011; Tuteja et al.

304 2016). SC knowledge and attitude scores significantly improved following the intervention course.

305 Post-intervention, participants were more interested in expanding their knowledge about SCs and

306 considered well-structured programs or training courses as a successful approach to improve their

307 understanding of SCs. The participants reported positive attitudes regarding the integration of SC

308 education in medical college curricula after the intervention. This study provides a shred of

309 landmark evidence from the Middle East and North Africa to implement the interactive learning

310 approach in the SC teaching field. The excellent knowledge and attitude regarding SCs could be

311 of great benefits not only to medical students but also to the overall health system as it will reflect

312 on future healthcare providers being more informed and better guided to serve their patients with

313 up-to-date information and improve the decision making power regarding SCs as an innovative

314 method of therapy (Perlow 2006; Tork et al. 2017; Tuteja et al. 2016). This study could enhance

315 medical curriculum development and teaching approaches and bridge the gap between basic

316 sciences and clinical practice.

As future health care leaders, medical students represent a source of information, or misinformation, which may influence patients' behaviors and serve as a valuable source of information (Davies et al. 2002). This makes the medical school an ideal place to address information misconceptions and emphasize positive attitudes toward SC applications. Therefore, improvements in the region's medical curricula should seriously consider interactive session

322 models and introduce broader and more scientific resources for students in the healthcare field.

323 This is especially true to follow-up on rapidly advancing scientific topics in the medical fields,

324 where relying merely on available evidence from textbooks may introduce delays in transferring 325 knowledge to medical students. 

about SCs, with the lowest scores observed for SC research knowledge, therapeutic uses, and basic knowledge. However, their knowledge regarding the SC potential applications was relatively good. Following the intervention course, the students' knowledge was significantly enhanced with better-reported scores, such as SC research knowledge. Significant improvements also spread to the other addressed knowledge domains regarding SCs, including SC basic knowledge, and that knowledge related to SC potential applications, and to a lesser extent, SC therapeutic uses' knowledge. Previous educational interventions successfully increased the knowledge about SC transplantation and banking among medical, nursing, and law students and showed more positive attitudes toward SC donation following a particular intervention (Azzazy \& Mohamed 2016; Kaya et al. 2015). Innovative SC education using practical experiments to master SC culture and differentiation techniques were also reported to deepen medical students' understanding of regenerative and translational medicine (Jin et al. 2018). After reviewing the educational interventions that were used in other studies to enhance the students' knowledge regarding SCs, we found that their educational interventions were for a shorter duration than ours, and they did not use such interactive teaching methods (Azzazy \& Mohamed 2016; Jin et al. 2018; Kaya et al. 2015). Thus, in our study, we were keen to provide a more comprehensive and detailed interactive teaching course for a longer duration that will cover more topics related to SC education, research, and potential applications, unproven SC therapies and tourism, and bioethics in order to design the interactive teaching course in an innovative way that will be more engaging to the medical students

346 (Azzazy \& Mohamed 2016; Jin et al. 2018; Kaya et al. 2015). Besides, study material developed

347 by our research team could be adopted by other schools interested in establishing similar courses, and our interactive teaching courses could be integrated within curricula. 
In the current study, the most common sources of knowledge regarding SCs were lectures

350 followed by social media. Social media has created an opportunity to disseminate information

351 regarding unproven SC-based therapies directly to consumers to legitimize providers and their

352 products by using solid emotional appeals such as patient testimonials (Lyons et al. 2021). Other

353 than social media, mass media, including newspapers, television, and radio, are considered a

354 primary source of scientific communication to the public as it can significantly influence public

355 attitudes toward controversial emerging technologies in regenerative medicine, such as the use of

356 leftover blastocysts as a source for embryonic SCs and genome editing (Sharpe et al. 2016). Also,

357 the portrayal of translational SC research in newspapers is highly optimistic and may foster

358 unrealistic expectations regarding clinical translation speed (Kamenova \& Caulfield 2015).

359 Medical students should consider other sources for knowledge based on scientific evidence, such

360 as medical journals and conferences. Unfortunately, none of the medical students in our study

361 chose panel discussions as a source for SC knowledge, despite being considered a valuable way to

362 trigger an exchange of viewpoints regarding ethical controversies surrounding SCs (Arráez-

363 Aybara et al. 2018). Therefore, medical schools are invited to further invest in students' knowledge

364 about SCs by enhancing exposure to updated medical literature and medical conferences.

This study indicates that the interactive teaching approach effectively improved the levels

of knowledge and positive attitudes toward SCs. Furthermore, our interactive learning approach

was sufficient to reduce gender gaps in SC knowledge scores, especially the scores related to SC

368 potential applications and SC research since females were significantly less knowledgable than

males in the pre-intervention course; however, the gender differences were reduced after the

370 intervention course and became statistically insignificant. Despite the evolving amount of

371 literature indicating the merits of the interactive learning approach, there is still a large gap between 
372 educational research and what happens in practice. The traditional didactic lectures still

373 predominate in university classrooms (Liebert et al. 2016; Merideno et al. 2015; Saroyan \& Snell

374 1997).

Previous studies that compared active learning to the traditional approach using passive

376

377

378

379

380

381

382

383

384

385

386

387

388

389

390

391

392

393

learning indicated that interactive teaching methods generally result in longer retention of material, superior problem-solving and higher-thinking skills, more positive attitudes, and higher motivation the students to learn (DIJK \& JOCHEMS 2002; Dodiya et al. 2019; McKeachie 1990; Wheijen et al. 2002). Also, the students found such classes more fun and less tedious, and they were more satisfied with this teaching approach (DIJK \& JOCHEMS 2002). Miller et al. reported a statistically significant higher average of students' performance on exams using engaging lectures compared with traditional didactic lectures (Miller et al. 2013). Also, the authors observed increased effectiveness of lectures, decreased distractions, and increased students' confidence with the material using interactive teaching methods (Miller et al. 2013). Based on our observations while conducting this study and the enrolled students' feedbacks, the experience of interactive teaching technique was interesting for both students and researchers, and many of the students were enthusiastic about more courses designed with this approach. However, many challenges facing the incorporation of interactive teaching methods, including the limited amount of scientific content that could be covered within the class time, the significant efforts of preparation required by the instructor to create the interactive activities, and the effects of this approach on time available for traditional lectures. Given the rapidly growing amount of knowledge and the unlimited access of students to the information through the internet and other technologies, it may be more important to teach students how to use information rather than learning specific facts. 
394 This objective could be achieved by implementation of interactive teaching methods. Thus,

395 medical educators may need to shift the importance of concept over content.

In our study, the participants showed relatively positive attitudes toward SCs before the

397 intervention, and furthermore, their attitudes improved following the intervention even to a lower extent than that observed in knowledge domains. However, negative attitudes related to SC religious controversies actually worsened the post-intervention course. Complex social, legal, ethical, and religious issues arise when emerging biotechnology involves human subjects (AlAqeel 2005), especially in conservative societies. However, Islamic teachings have paid attention to disease prevention and health promotion, and it is crucial to focus more on increasing our understanding of how SC applications could advance the health of human beings to facilitate the adoption of these technologies (Bouzenita 2017). Within this context, future SC-related interventions should focus on incorporating religious leaders from the medical community to present their points of view related to scientific facts from ethical, moral, and religious perspectives (Aksoy 2005; Al-Tabba et al. 2020; Fadel 2012). The current Statute regarding SC use in developing countries is still unclear and not updated; thus, experts of different political, religious, scientific, and medical aspects who are familiar with laws are invited to develop a more comprehensive juridical system (Al-Tabba et al. 2020; Pourebrahim et al. 2020). However, although the negative attitudes toward ethical controversies surrounding SC therapies worsened following the intervention; the change in mean attitude scores was not statistically significant.

413 Ethical concerns may be tightly connected to religious concerns and can only be mitigated by openly discussing the lack of religious restrictions related to medical improvements. 
417 reported to be the obstacle that have obscured the proper potential use of SCs for revolutionizing

418 medicine and treatment options in the future (Hug 2005). Medical curricula need to be restructured

419 to include SCs or other emerging technologies in biomedicine and include research and healthcare

420 ethics (Abdulrazeq et al. 2019; Brass 2009; Sarkadi \& Schatten 2012). Adopting new technologies

421 for patient care is challenging since many ethical dilemmas surround it, and future physicians

422 should be prepared to deal with such dilemmas when they arise (Curley \& Sharples 2006).

A few limitations should be mentioned. The sample size was relatively small, and the participants were selected from a single medical school, limiting our results' generalizability.

While response and enrolment rates were not optimal, they are considered sufficient among medical students. Data collection in this study was also limited to quantitative methods; utilizing a qualitative approach supported by quantitative methods would be recommended to provide a richer analysis of the phenomena. A parallel-group with no intervention was not utilized which may introduce testing effects and exacerbate the results. The same survey was utilized pre-and post-intervention that was self-reported by the participants, which might explain that the improvements in knowledge and attitudes scores could be by chance and not due to intervention effects. Finally, this study used an interactive educational approach over a six-week course to improve the students' knowledge and attitudes toward the SC field without comparison with other learning approaches. It would be interesting for future studies to compare the effectiveness of this interactive educational approach with other types of learning, such as flipped classrooms and traditional dedicated lectures.

\section{Conclusions}


440 students' knowledge and attitudes toward SCs, therapeutic uses, and potential research

441 applications. The study results have proven poor knowledge about SCs in the pre-intervention

442 phase, with a significant improvement after the interactive intervention course. As SC utilization

443 becomes more common across specialties, having pre-clinical and clinical curricula educate future

444 physicians on SCs is necessary. Thus, the SC concept such as research skills and SC therapeutic

445 uses should be incorporated into the medical school curriculum to overcome the current

446 shortcomings in SC knowledge and update future physicians with evidence-based medical

447 practice. The study findings also indicate the effectiveness of the intervention course in achieving

448 more positive attitudes toward SCs by the medical students. In addition, the differences in

449 knowledge regarding SCs between males and females have reduced after the intervention course.

450 Thus, the study concluded that an interactive teaching approach might be feasible under the same

451 teaching resources and students' situations, and thus, it could be considered beneficial to the

452 medical students regardless of gender. Educators can capitalize on the available opportunities to

453 improve the areas of the current SC curricula. Although the interactive intervention course was as

454 short as six weeks, the study outcomes were promising. The appropriate intervention methods

455 should be further tested by their implementation on a large scale in most medical subjects. Also,

456 medical educators and schools are calling for integrating new interactive teaching approaches to

457 address the life sciences instead of traditional teaching methods. Further studies with a larger

458 sample are recommended to evaluate the needed curriculum content development, practical

459 teaching approaches, and the most effective practice matters. Moreover, developing educational

460 programs considering social, ethical, legal, religious, and cultural issues are recommended. 
474 Compliance with Ethical Standards:

475 All procedures performed in this study involving human participants were reviewed and ethically

476 approved by the Institutional Review Board (IRB) of the research and ethics committee at the

477 University of Science and Technology Yemen-Jordan branch (USTY-Jo) (IRB number,

478 9/120/2019). This study was conducted following the 1975 Helsinki declaration, as revised in 4792008 and later amendments or comparable ethical standards.

\section{Informed consent:}

481 Written informed consent was obtained from all individual participants included in the study. 


\section{Availability of data and materials:}

483 The datasets generated and analyzed during the current study are provided in supplementary file

484 2. The data demonstrate the participants' responses pre- and post-intervention.

485 Declaration of interests:

486 The authors declare that they have no competing interests. No financial or other relationship could 487 lead to a conflict of interest. No writing assistance was aided in the preparation of the manuscript.

\section{$488 \quad$ Funding}

489 The authors received no funding for this work.

490 Acknowledgment:

491 We would like to thank the faculty of graduate studies for supporting the conduct of this research. 
493

494

495

496

497

498

499

500

501

502

503

504

505

506

507

508

509

510

511

512

513

514

515

516

517

518

519

520

521

522

523

524

525

526

527

528

529

530

531

532

533

534

535

536

537

538

539

References

Abdulrazeq F, Al-Maamari A, Ameen W, and Ameen A. 2019. Knowledge, Attitudes and Practices of Medical Residents towards Healthcare Ethics in the Islamic Hospital, Jordan. Yemeni Journal for Medical Sciences 13:1-9.

Aksoy S. 2005. Making regulations and drawing up legislation in Islamic countries under conditions of uncertainty, with special reference to embryonic stem cell research. J Med Ethics 31:399-403. 10.1136/jme.2003.005827

Al-Aqeel Al. 2005. Ethical guidelines in genetics and genomics. An Islamic perspective. Saudi Med J 26:1862-1870.

Al-Tabba A, Dajani R, and Al-Hussaini M. 2020. Stem Cell Statute in Jordan: Leading the Way. Front Genet 11:657. 10.3389/fgene.2020.00657

Arráez-Aybara L-A, Villanueva-Orbáizb R, Catón-Vázqueza FJ, Garcia-Gómeza S, and Bueno-Lópezc JL. 2018. The role of an expert discussion panel on shaping the views of the undergraduate in health sciences on the use of stem cells and pre-implantation embryos. EducationMedica 21:313-323. 10.1016/j.edumed.2018.10.010

Azzazy HM, and Mohamed HF. 2016. Effect of educational intervention on knowledge and attitude of nursing students regarding stem cells therapy. IOSR Journal of Nursing and Health Science 5:7580.

Bouzenita Al. 2017. "Harvesting" and Use of Human (Embryonic) Stem Cells: An Islamic Evaluation. J Bioeth Inq 14:97-108. 10.1007/s11673-016-9757-6

Brass EP. 2009. Basic biomedical sciences and the future of medical education: implications for internal medicine. J Gen Intern Med 24:1251-1254. 10.1007/s11606-009-0998-5

Chang YH, Wu KC, Harn HJ, Lin SZ, and Ding DC. 2018. Exosomes and Stem Cells in Degenerative Disease Diagnosis and Therapy. Cell Transplant 27:349-363. 10.1177/0963689717723636

Curley D, and Sharples A. 2006. Ethical questions to ponder in the European stem cell patent debate. $J$ Biolaw Bus 9:12-16.

Davies M, Corney A, Conlon S, Freeman R, Claridge S, Crawford R, and Mohiddin A. 2002. The impact of health professionals' attitudes about being registered donors on the availability of organs. Nursing times 98:36-39.

DIJK LAV, and JOCHEMS WMG. 2002. Changing a traditional lecturing approach into an interactive approach: Effects of interrupting the monologue in lectures. International Journal of Engineering Education 18:275-284.

Dodiya D, Vadasmiya DS, and Diwan J. 2019. A comparative study of flip classroom teaching method versus traditional classroom teaching method in undergraduate medical students in physiology. Natl J Physiol Pharm Pharmacol 9: 551-555. 10.5455/njppp.2019.9.0310829032019

Fadel HE. 2012. Developments in stem cell research and therapeutic cloning: Islamic ethical positions, a review. Bioethics 26:128-135. 10.1111/j.1467-8519.2010.01840.x

Gupta A, BhattiK W, and AgnihotriP K. 2015. Implementation of Interactive Teaching Learning Methods in Large Group in Endocrine Pharmacology. Ind J Pharmac and Pharmaco 2:197-202.

Hug K. 2005. Sources of human embryos for stem cell research: ethical problems and their possible solutions. Medicina (Kaunas) 41:1002-1010.

Jin C, Tian H, Li J, Jia S, Li S, Xu GT, Xu L, and Lu L. 2018. Stem cell education for medical students at Tongji University: Primary cell culture and directional differentiation of rat bone marrow mesenchymal stem cells. Biochem Mol Biol Educ 46:151-154. 10.1002/bmb.21098

Kamenova K, and Caulfield T. 2015. Stem cell hype: media portrayal of therapy translation. Science translational medicine 7:278ps274-278ps274.

Peer] reviewing PDF | (2021:10:66942:1:0:NEW 26 Dec 2021) 
540

541

542

543

544

545

546

547

548

549

550

551

552

553

554

555

556

557

558

559

560

561

562

563

564

565

566

567

568

569

570

571

572

573

574

575

576

577

578

579

580

581

582

583

584

585

586
Kaur D, Singh J, Seema MA, and Kaur G. 2011. Role of interactive teaching in medical education. Int J Basic Appl Med Sci 1:54-60.

Kaya Z, Gültekin KE, Demirtaş OK, Karadeniz D, Calapkulu Y, and Tap Ö. 2015. Effects of targeted education for first-year university students on knowledge and attitudes about stem cell transplantation and donation. Experimental and Clinical Transplantation 13:76-81.

Knoepfler PS. 2013. Call for fellowship programs in stem cell-based regenerative and cellular medicine: new stem cell training is essential for physicians. Regen Med 8:223-225. 10.2217/rme.13.1

Kwon SG, Kwon YW, Lee TW, Park GT, and Kim JH. 2018. Recent advances in stem cell therapeutics and tissue engineering strategies. Biomater Res 22:36. 10.1186/s40824-018-0148-4

Liebert CA, Mazer L, Bereknyei Merrell S, Lin DT, and Lau JN. 2016. Student perceptions of a simulationbased flipped classroom for the surgery clerkship: A mixed-methods study. Surgery 160:591-598. 10.1016/j.surg.2016.03.034

Ling Y, Swanson DB, Holtzman K, and Bucak SD. 2008. Retention of basic science information by senior medical students. Acad Med 83:S82-85. 10.1097/ACM.0b013e318183e2fc

Lovell-Badge R, Anthony E, Barker RA, Bubela T, Brivanlou AH, Carpenter M, Charo RA, Clark A, Clayton E, Cong Y, Daley GQ, Fu J, Fujita M, Greenfield A, Goldman SA, Hill L, Hyun I, Isasi R, Kahn J, Kato K, Kim J-S, Kimmelman J, Knoblich JA, Mathews D, Montserrat N, Mosher J, Munsie M, Nakauchi H, Naldini L, Naughton G, Niakan K, Ogbogu U, Pedersen R, Rivron N, Rooke H, Rossant J, Round J, Saitou M, Sipp D, Steffann J, Sugarman J, Surani A, Takahashi J, Tang F, Turner L, Zettler PJ, and Zhai X. 2021. ISSCR Guidelines for Stem Cell Research and Clinical Translation: The 2021 update. Stem Cell Reports 16:1398-1408. https://doi.org/10.1016/j.stemcr.2021.05.012

Lye JL, Soon LK, Wan Ahmad WA, and Tan SC. 2015. Knowledge and Attitude about Stem Cells and Their Application in Medicine among Nursing Students in Universiti Sains Malaysia, Malaysia. Malays J Med Sci 22:23-31.

Lyons S, Salgaonkar S, and Flaherty GT. 2021. International stem cell tourism: a critical literature review and evidence-based recommendations. International Health. 10.1093/inthealth/ihab050

McKeachie WJAO. 1990. Teaching and Learning in the College Classroom: A Review of the Literature, 2nd ed.: National Center for Research to Improve PostseconotoxyTeaching and Learning, Ann Arbor, MI.

Merideno I, Antón R, and Prada JG. 2015. The influence of a non-linear lecturing approach on student attention: Implementation and assessment \%J Ingeniería e Investigación. 35:115-120.

Miller CJ, McNear J, and Metz MJ. 2013. A comparison of traditional and engaging lecture methods in a large, professional-level course. Adv Physiol Educ 37:347-355. 10.1152/advan.00050.2013

NYSCF. 2017. What are stem cells? Available at https://nyscf.org/stem-cell-basics/what-are-stem-cells/ (accessed June 10, 2021.

Perlow JH. 2006. Patients' knowledge of umbilical cord blood banking. J Reprod Med 51:642-648.

Pershing S, and Fuchs VR. 2013. Restructuring medical education to meet current and future health care needs. Acad Med 88:1798-1801. 10.1097/acm.0000000000000020

Pierret C, and Friedrichsen P. 2009. Stem cells and society: an undergraduate course exploring the intersections among science, religion, and law. CBE Life Sci Educ 8:79-87. 10.1187/cbe.08-09-0053

Pourebrahim A, Goldouzian I, and Ramezani A. 2020. Investigation of Stem cells Technology in The Light of Jurisprudential Documents. Cell J 22:121-127. 10.22074/cellj.2020.5694

Protze SI, Lee JH, and Keller GM. 2019. Human Pluripotent Stem Cell-Derived Cardiovascular Cells: From Developmental Biology to Therapeutic Applications. Cell Stem Cell 25:311-327. 10.1016/j.stem.2019.07.010

Sarkadi B, and Schatten G. 2012. Stem cell course in the Middle East: science diplomacy and international collaborations during the Arab spring. Stem Cell Rev Rep 8:87-90. 10.1007/s12015-011-9277-z

PeerJ reviewing PDF | (2021:10:66942:1:0:NEW 26 Dec 2021) 
587 Saroyan A, and Snell LS. 1997. Variations in lecturing styles. Higher Education 33:85-104.

588

589

590

591

592

593

594

595

596

597

598

599

600

601

602

603

604

605

606

607

608

609

610

611

612

613

614

615
Scott CT. 2015. Backward by Design: Building ELSI into a Stem Cell Science Curriculum. Hastings Cent Rep 45:26-32. 10.1002/hast.448

Sharpe K, Di Pietro N, and Illes J. 2016. In the Know and in the News: How Science and the Media Communicate About Stem Cells, Autism and Cerebral Palsy. Stem Cell Rev Rep 12:1-7. 10.1007/s12015-015-9627-3

SUEN SSH, LAO TT, CHAN OK, KOU TKO, CHAN SCS, KIM JH, LAU TK, and LEUNG TY. 2011. Maternal understanding of commercial cord blood storage for their offspring - a survey among pregnant women in Hong Kong. 90:1005-1009. https://doi.org/10.1111/j.1600-0412.2011.01201.x

Tork H, ALRaffaa S, ALMutairi K, ALShammari N, ALHarbi A, and ALOnzi A. 2017. Stem cells: knowledge and attitude among health care providers in Qassim region, KSA. 2017 7:7\%J International Journal of Advanced Nursing Studies. 10.14419/ijans.v7i1.8524

Tuteja M, Agarwal M, and Phadke SR. 2016. Knowledge of Cord Blood Banking in General Population and Doctors: A Questionnaire Based Survey. The Indian Journal of Pediatrics 83:238-241. 10.1007/s12098-015-1909-x

Wheijen C, Jones A, and Rainer K. 2002. Interactive Teaching Approach in Year One University Physics in Taiwan: Implementation and Evaluation. Asia-Pacific Forum on Science Learning and Teaching. 
621 Figure 1. The reported sources of knowledge about stem cells before the intervention course 
Figure 1

The reported sources of knowledge about stem cells before the intervention course

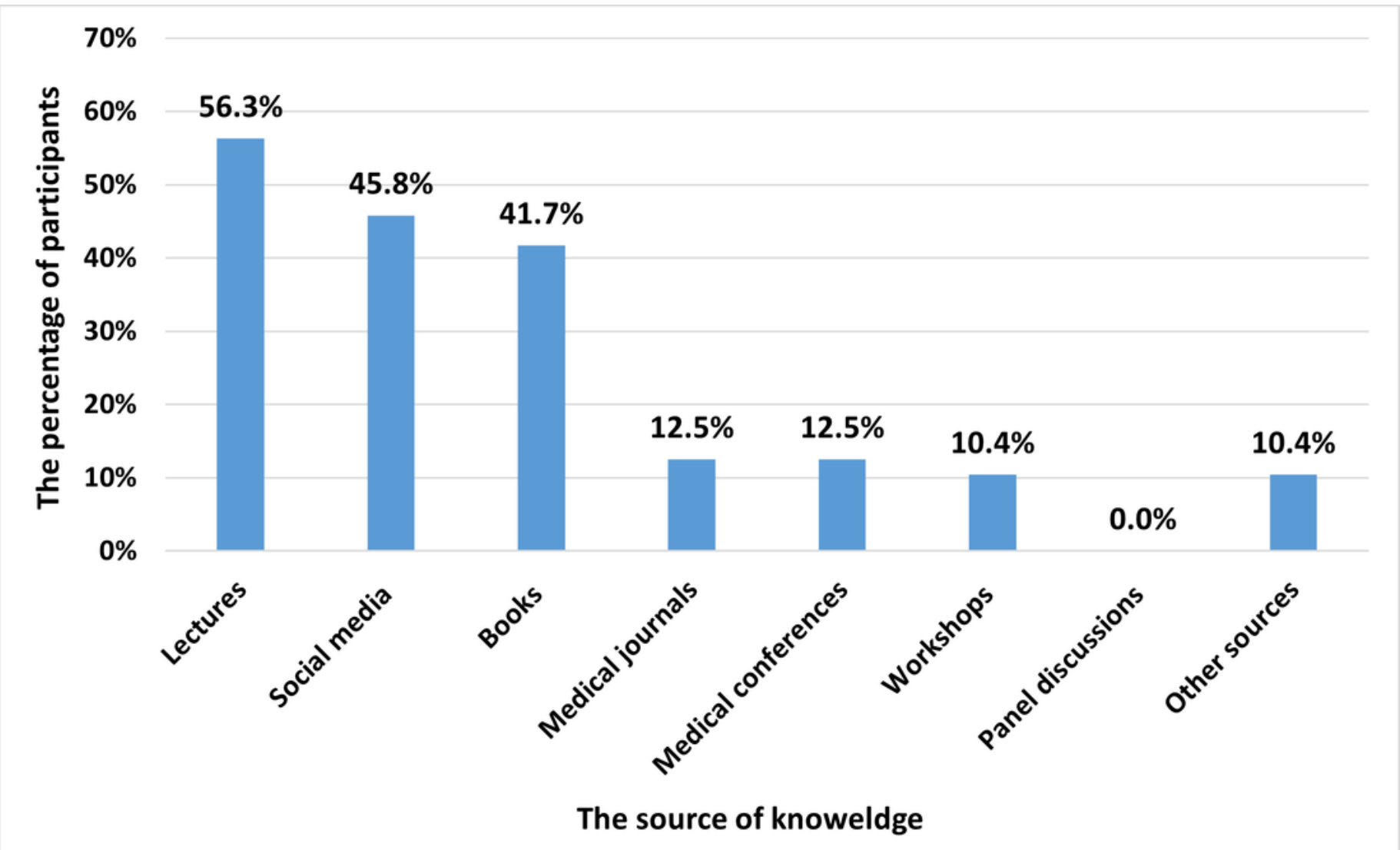


Table $\mathbf{1}$ (on next page)

Detailed Study Intervention 
1 Table 1. Detailed Study Intervention

\begin{tabular}{|c|c|c|}
\hline $\begin{array}{l}\text { Number and title of intervention } \\
\text { week }\end{array}$ & Objectives of the intervention & Interactive teaching methods \\
\hline Week one: Stem cell basic biology & $\begin{array}{l}\checkmark \text { Reviewing the history of stem cell (SC) } \\
\text { research. } \\
\checkmark \text { Understanding the basic biology of SCs and } \\
\text { identifying characteristics that distinguish SCs } \\
\text { from other types of cells. } \\
\checkmark \text { Classifying SCs according to source and } \\
\text { potency. }\end{array}$ & $\begin{array}{l}\text { Brainstorming: The lecturer asked students an } \\
\text { opening question: what do you know about } \\
\text { SCs?, then he used the whiteboard to list all the } \\
\text { ideas generated by the students and grouped } \\
\text { them into few headlines. } \\
\text { Visual aids: The lecturer presented a short } \\
\text { video about the discovery of the microscope by } \\
\text { Robert Hooke, and then he presented a diagram } \\
\text { illustrating major historical events in SC } \\
\text { research. }\end{array}$ \\
\hline Week two: Stem cell potential applications & $\begin{array}{l}\text { Recognizing potential applications of SCs in } \\
\text { studying early human development, modeling } \\
\text { diseases in a culture dish, testing new drugs, and } \\
\text { restoring lost tissues. }\end{array}$ & $\begin{array}{l}\text { Group activity and learning by teaching: } \\
\text { Students were divided into eight groups and } \\
\text { were given one of four topics that cover } \\
\text { potential applications of SCs. Each group had } \\
\text { to read five articles about the topic and do a } \\
\text { seminar for other students. }\end{array}$ \\
\hline $\begin{array}{l}\text { Week three: Unproven stem cell therapies } \\
\text { and stem cell tourism }\end{array}$ & $\begin{array}{l}\checkmark \text { Listing current therapeutic uses of SCs such as } \\
\text { bone marrow transplantation for leukemia. } \\
\checkmark \text { Shedding light on potential therapeutic uses of } \\
\text { SCs such as limbal SCs for degenerative eye } \\
\text { diseases. } \\
\checkmark \text { Increasing awareness about SC tourism and } \\
\text { severe risks due to trying unproven SC } \\
\text { therapies. }\end{array}$ & $\begin{array}{l}\text { Case-based scenarios: for patients who tried } \\
\text { unproven SC therapies. } \\
\text { Group activity: students were divided into } \\
\text { eight groups assigned to search for websites } \\
\text { that promote unproven SC therapies. }\end{array}$ \\
\hline
\end{tabular}




\begin{tabular}{|c|c|c|}
\hline Week four: Stem cell research & $\begin{array}{l}\checkmark \text { Understanding the induced pluripotent stem } \\
\text { cells (iPSCs) and the role of transcription } \\
\text { factors. } \\
\checkmark \text { Explaining SC-assisted technologies such as } \\
\text { MRT, SCNT, and human/animal chimeras. }\end{array}$ & $\begin{array}{l}\text { Story: a reflection on Shinya Yamanaka's } \\
\text { story, who won Nobel Prize for discovering } \\
\text { induced pluripotent SCs. }\end{array}$ \\
\hline Week five: Cord blood banking and donation & $\begin{array}{l}\checkmark \text { Explaining techniques and procedures of cord } \\
\text { blood collection, banking, and donation. } \\
\checkmark \text { Summarizing advantages and disadvantages of } \\
\text { cord blood transplantation in comparison with } \\
\text { bone marrow transplantation. } \\
\checkmark \text { Comparing between different types of Cord } \\
\text { blood banks. }\end{array}$ & $\begin{array}{l}\text { Role-playing: Students played different roles } \\
\text { assigned to them: parents who are interested in } \\
\text { cord blood banking and healthcare providers } \\
\text { who should answer parents' questions. } \\
\text { Guest lecturer: to take about cord blood } \\
\text { banking. } \\
\text { Real-life situations: students provided health } \\
\text { education for pregnant women about cord } \\
\text { blood banking. }\end{array}$ \\
\hline Week six: bioethics of stem cell research & $\begin{array}{l}\text { Discussing ethical controversies surrounding SC } \\
\text { research and their-assisted technologies. }\end{array}$ & $\begin{array}{l}\text { Panel discussion: with bioethics expert. } \\
\text { Class debate: Class was divided into eight } \\
\text { groups; four groups argued for another four } \\
\text { groups against research involving embryonic } \\
\text { SCs. }\end{array}$ \\
\hline
\end{tabular}

2 


\section{PeerJ}


Table 2 (on next page)

Respondents' Characteristics $(n=48)$

Abbreviations: $M=$ Mean; $S D=$ Standard Deviation. 
2 Table 2. Respondents' Characteristics $(n=48)$

\begin{tabular}{|c|c|}
\hline Characteristics & Value \\
\hline \multicolumn{2}{|l|}{ Gender, $N(\%)$} \\
\hline Male & $32(66.7 \%)$ \\
\hline Female & $16(33.3 \%)$ \\
\hline Age, $M(S D)$ & $24.0(1.2)$ \\
\hline \multicolumn{2}{|l|}{ Nationality, $N(\%)$} \\
\hline Jordanian & $14(29.2 \%)$ \\
\hline Palestinian & $3(6.3 \%)$ \\
\hline Syrian & $8(16.7 \%)$ \\
\hline Iraqi & $6(12.5 \%)$ \\
\hline Yemeni & $13(27.1 \%)$ \\
\hline Others & $4(8.3 \%)$ \\
\hline
\end{tabular}




\section{Table 3 (on next page)}

Pre- and post-educational intervention mean knowledge scores and differences $(n=48)$

Abbreviations: $M=$ Mean; $S D=$ Standard Deviation; Min = Minimum score; Max = Maximum score; $C l=$ Confidence Interval; $M D=$ Mean Difference; Pre = Pre-educational intervention; Post = Post-educational intervention

* Significant at $p<0.05$ based on paired-samples t-test.

† The code was reversed for the false or misleading statements to be "Four = Strongly Disagree" and "Zero = Strongly Agree".

Note: The total score of knowledge is the sum of the statements' scores for the four major domains (stem cell basic knowledge, potential applications, therapeutic uses, and research) for each participant divided by 27. 
1 Table 3. Pre- and post-educational intervention mean knowledge scores and differences $(n=48)$

\begin{tabular}{|c|c|c|c|c|c|c|c|}
\hline \multicolumn{4}{|c|}{$\begin{array}{l}\text { Pre- and post-educational intervention mean scores of students' knowledge regarding stem cells, } \\
\text { their potential applications, therapeutic uses, and research involving them }\end{array}$} & \multicolumn{4}{|c|}{$\begin{array}{l}\text { Differences between pre-and } \\
\text { post-educational interventions }\end{array}$} \\
\hline Stem cells: basic knowledge & Score & $M(S D)$ & $\begin{array}{l}\text { Min- } \\
\text { Max }\end{array}$ & $M D$ & \multicolumn{2}{|c|}{$\begin{array}{c}95 \% \text { CI } \\
\text { Lower Upper }\end{array}$} & p-value \\
\hline \multirow{2}{*}{$\begin{array}{l}\text { 1- I have sufficient knowledge of different types of stem cells, such as } \\
\text { adult and embryonic stem cells. }\end{array}$} & Pre & $1.88(0.94)$ & $0-4$ & \multirow[t]{2}{*}{1.89} & \multirow[t]{2}{*}{1.57} & \multirow[t]{2}{*}{2.23} & \multirow[t]{2}{*}{$<0.001 *$} \\
\hline & Post & $3.77(0.43)$ & $3-4$ & & & & \\
\hline \multirow[t]{2}{*}{ 2- I have sufficient knowledge of the sources of stem cells. } & Pre & $2.17(0.7$ & $0-4$ & \multirow[t]{2}{*}{1.50} & \multirow[t]{2}{*}{1.22} & \multirow[t]{2}{*}{1.78} & \multirow[t]{2}{*}{$<0.001 *$} \\
\hline & Post & $3.67(0$. & $2-4$ & & & & \\
\hline \multirow[t]{2}{*}{ 3- I have sufficient knowledge of the therapeutic uses of stem cells. } & Pre & 2.15 & $0-4$ & \multirow[t]{2}{*}{1.54} & \multirow[t]{2}{*}{1.22} & \multirow[t]{2}{*}{1.86} & \multirow[t]{2}{*}{$<0.001^{*}$} \\
\hline & Post & $3.69(0.5$ & $2-4$ & & & & \\
\hline \multirow{2}{*}{$\begin{array}{l}\text { 4- I have sufficient knowledge of the three germ layers (endoderm, } \\
\text { mesoderm and ectoderm), and organs and tissues generated from } \\
\text { each layer. }\end{array}$} & Pre & 2.67 & $0-4$ & \multirow[t]{2}{*}{1.02} & \multirow[t]{2}{*}{0.70} & \multirow[t]{2}{*}{1.34} & \multirow[t]{2}{*}{$<0.001^{*}$} \\
\hline & Post & $3.69(0.59)$ & $2-4$ & & & & \\
\hline \multirow{2}{*}{$\begin{array}{l}\text { 5- Cell differentiation is the process by which stem cells become more } \\
\text { specialized cell types (true). }\end{array}$} & Pre & & $1-4$ & \multirow[t]{2}{*}{0.65} & \multirow[t]{2}{*}{0.38} & \multirow[t]{2}{*}{0.92} & \multirow[t]{2}{*}{$<0.001^{*}$} \\
\hline & Post & 3.50 & $1-4$ & & & & \\
\hline \multirow{2}{*}{$\begin{array}{l}\text { 6- As a stem cell differentiates, it gradually loses potency and becomes } \\
\text { unipotent (true). }\end{array}$} & Pre & 2.23 & $0-4$ & \multirow[t]{2}{*}{0.48} & \multirow[t]{2}{*}{0.13} & 0.83 & $0.009 *$ \\
\hline & Post & 2.7 & $0-4$ & & & & \\
\hline 7- Self-renewing is the ability of a stem cell to produce more stem cells & Pre & 2.46 & $0-4$ & 0.89 & 0.60 & 1.20 & $<0.001 *$ \\
\hline & Post & 3.35 & $1-4$ & & & & \\
\hline 8- Adult stem cells are pluripotent cells that have the potential to make & Pre & 1.58 & $0-4$ & 1.34 & 0.75 & 1.92 & $<0.001 *$ \\
\hline & Post & 2.92 & $0-4$ & & & & \\
\hline 9- Bone marrow is the only source for adult stem cells (false). $\dagger$ & Pre & 2.17 & $0-4$ & 1.10 & 0.67 & 1.54 & $<0.001 *$ \\
\hline & Post & 3.27 & $0-4$ & & & & \\
\hline 10- Stem & Pre & 2.73 & $0-4$ & 0.52 & 0.12 & 0.93 & $0.013 *$ \\
\hline & Post & 3.25 & $0-4$ & & & & \\
\hline 11- Embryonic stem cells are derived from leftover blastocysts after in & Pre & $2.06(0.76)$ & $0-4$ & 0.90 & 0.48 & 1.31 & $<0.001 *$ \\
\hline & Post & $2.96(1.34)$ & $0-4$ & & & & \\
\hline 12- Embryonic stem cells are derived from the umbilical cord after & Pre & $1.35(0.91)$ & $0-3$ & 0.38 & -0.16 & 0.91 & 0.165 \\
\hline & Post & $1.73(1.65)$ & $0-4$ & & & & \\
\hline 13- Embryonic stem cells are derived from the trophoblast of & Pre & $1.54(0.65)$ & $0-4$ & 0.25 & -0.25 & 0.75 & 0.316 \\
\hline blastocysts (false) $\cdot \dagger$ & Post & $1.79(1.64)$ & $0-4$ & & & & \\
\hline
\end{tabular}


3 Table 3. (Continued).

\begin{tabular}{|c|c|c|c|c|c|c|c|}
\hline \multicolumn{4}{|c|}{$\begin{array}{l}\text { Pre- and post-educational intervention mean scores of students' knowledge regarding stem cells, } \\
\text { their potential applications, therapeutic uses, and research involving them }\end{array}$} & \multicolumn{4}{|c|}{$\begin{array}{l}\text { Differences between pre-and } \\
\text { post-educational interventions }\end{array}$} \\
\hline Stem cells: potential applications & Score & $M(S D)$ & $\begin{array}{l}\text { Min- } \\
\operatorname{Max}\end{array}$ & $M D$ & \multicolumn{2}{|c|}{$\begin{array}{l}95 \% C I \\
\text { Lower } \\
\text { Upper }\end{array}$} & p-value \\
\hline \multirow[t]{2}{*}{ 14- Stem cells can be used to study early human development (true). } & Pre & $3.02(0.84)$ & $1-4$ & \multirow[t]{2}{*}{0.40} & \multirow[t]{2}{*}{0.13} & \multirow[t]{2}{*}{0.66} & \multirow[t]{2}{*}{$0.004 *$} \\
\hline & Post & $3.42(0.71)$ & $1-4$ & & & & \\
\hline \multirow{2}{*}{$\begin{array}{l}\text { 15- Stem cells can be used to understand the pathophysiology and } \\
\text { analyze disease mechanisms by modeling disease in a culture dish } \\
\text { outside the human body (true). }\end{array}$} & Pre & $2.56(1.09)$ & $0-4$ & \multirow[t]{2}{*}{0.92} & \multirow[t]{2}{*}{0.48} & \multirow[t]{2}{*}{1.35} & \multirow[t]{2}{*}{$<0.001^{*}$} \\
\hline & Post & $3.48(0.83)$ & $0-4$ & & & & \\
\hline \multirow{2}{*}{$\begin{array}{l}\text { 16- Stem cells can be used to test and screen new drug candidates and } \\
\text { toxins to figure out their potential side effects (true). }\end{array}$} & Pre & $2.21(1.09)$ & $0-4$ & \multirow[t]{2}{*}{1.27} & \multirow[t]{2}{*}{0.84} & \multirow[t]{2}{*}{1.70} & \multirow[t]{2}{*}{$<0.001^{*}$} \\
\hline & Post & $3.48(0.83)$ & $0-4$ & & & & \\
\hline \multirow{2}{*}{$\begin{array}{l}\text { 17- Stem cells can be used to replace or restore tissues that have been } \\
\text { damaged by disease or injury, such as diabetes, heart attacks, } \\
\text { Parkinson's disease, skin burns, or spinal cord injury (true). }\end{array}$} & Pre & $2.85(1.09)$ & $0-4$ & \multirow[t]{2}{*}{0.73} & \multirow[t]{2}{*}{0.38} & \multirow[t]{2}{*}{1.08} & \multirow[t]{2}{*}{$<0.001^{*}$} \\
\hline & Post & $3.58(0.85)$ & $0-4$ & & & & \\
\hline \multirow[t]{2}{*}{ The total score of stem cell potential applications } & Pre & \multicolumn{2}{|l|}{$2.66(0.77)$} & \multirow[t]{2}{*}{0.80} & \multirow[t]{2}{*}{0.53} & \multirow[t]{2}{*}{1.09} & \multirow[t]{2}{*}{$<0.001 *$} \\
\hline & Post & $3.46(0.59)$ & & & & & \\
\hline \multicolumn{8}{|l|}{ Stem cells: therapeutic uses } \\
\hline \multirow{2}{*}{$\begin{array}{l}\text { 18- There is a wide range of conditions or diseases for which stem cell } \\
\text { therapies have been proven to be safe and effective such as } \\
\text { osteoarthritis and multiple sclerosis (false). } \dagger\end{array}$} & Pre & $1.54(0.97)$ & $0-4$ & \multirow[t]{2}{*}{0.69} & \multirow[t]{2}{*}{0.23} & \multirow[t]{2}{*}{1.15} & \multirow[t]{2}{*}{$0.004^{*}$} \\
\hline & Post & $2.23(1.53)$ & $0-4$ & & & & \\
\hline \multirow{2}{*}{$\begin{array}{l}\text { 19- There is nothing to lose from trying unproven stem cell therapies } \\
\text { since they can provide hope for hopeful patients (false). } \dagger\end{array}$} & Pre & $1.71(1.07)$ & $0-4$ & 0.67 & 0.24 & 1.10 & $0.003 *$ \\
\hline & Post & $2.38(1.39)$ & $0-4$ & & & & \\
\hline 20- Bone marrow-derived stem cells will spontaneously regenerate & Pre & $1.88(1.00)$ & $0-4$ & 0.45 & -0.01 & 0.93 & 0.055 \\
\hline $\begin{array}{l}\text { into different cell types such as hepatocytes and neural cells } \\
\text { without manipulation in the lab (false). } \dagger\end{array}$ & Post & $2.33(1.53)$ & $0-4$ & & & & \\
\hline
\end{tabular}




\begin{tabular}{|c|c|c|c|c|c|c|c|}
\hline \multirow{2}{*}{$\begin{array}{l}\text { 21- If the balance is skewed between differentiation and self-renewing } \\
\text { properties of stem cells, it may result in tumor formation (true). }\end{array}$} & Pre & $2.25(0.79)$ & $0-4$ & \multirow[t]{2}{*}{0.63} & \multirow[t]{2}{*}{0.26} & \multirow[t]{2}{*}{0.99} & \multirow{2}{*}{$<0.001^{*}$} \\
\hline & Post & $2.88(1.04)$ & $1-4$ & & & & \\
\hline \multirow[t]{2}{*}{ The total score of stem cell therapeutic uses } & Pre & \multicolumn{2}{|l|}{$1.84(0.63)$} & \multirow[t]{2}{*}{0.61} & \multirow[t]{2}{*}{0.36} & \multirow[t]{2}{*}{0.85} & \multirow[t]{2}{*}{$<0.001 *$} \\
\hline & Post & \multicolumn{2}{|l|}{$2.45(0.80)$} & & & & \\
\hline
\end{tabular}

Table 3. (Continued).

\begin{tabular}{|c|c|c|c|c|c|c|c|}
\hline \multicolumn{4}{|c|}{$\begin{array}{l}\text { Pre- and post-educational intervention mean scores of students' knowledge regarding stem cells, } \\
\text { their potential applications, therapeutic uses, and research involving them. }\end{array}$} & \multicolumn{4}{|c|}{$\begin{array}{l}\text { Differences between pre-and } \\
\text { post-educational interventions. }\end{array}$} \\
\hline Stem cells: research & Score & $M(S D)$ & $\begin{array}{l}\text { Min- } \\
\operatorname{Max}\end{array}$ & $M D$ & \multicolumn{2}{|c|}{$\begin{array}{c}\text { 95\% CI } \\
\text { Lower } \\
\text { Upper }\end{array}$} & $p$-value \\
\hline \multirow{2}{*}{$\begin{array}{l}\text { 22- I would be confident to explain the induced-Pluripotent Stem Cells } \\
\text { (iPSCs). }\end{array}$} & Pre & $1.65(1.16)$ & $0-4$ & \multirow[t]{2}{*}{1.75} & \multirow[t]{2}{*}{1.38} & \multirow[t]{2}{*}{2.12} & \multirow[t]{2}{*}{$<0.001^{*}$} \\
\hline & Post & $3.40(0.71)$ & $2-4$ & & & & \\
\hline \multirow[t]{2}{*}{ 23- I would be confident to explain the transcription factors. } & Pre & $1.85(1.19)$ & $0-4$ & \multirow[t]{2}{*}{1.28} & \multirow[t]{2}{*}{0.87} & \multirow[t]{2}{*}{1.67} & \multirow[t]{2}{*}{$<0.001^{*}$} \\
\hline & Post & $3.13(0.89)$ & $0-4$ & & & & \\
\hline \multirow{2}{*}{$\begin{array}{l}\text { 24- Adult cells can be "reprogrammed" genetically to assume stem } \\
\text { cell-like state (true). }\end{array}$} & Pre & $1.85(1.05)$ & $0-4$ & \multirow[t]{2}{*}{1.46} & \multirow[t]{2}{*}{1.04} & \multirow[t]{2}{*}{1.88} & \multirow[t]{2}{*}{$<0.001^{*}$} \\
\hline & Post & $3.31(0.83)$ & $1-4$ & & & & \\
\hline \multirow{2}{*}{$\begin{array}{l}\text { 25- I would be confident to discuss the Somatic Cell Nuclear Transfer } \\
\text { (SCNT). }\end{array}$} & Pre & $1.58(1.07)$ & $0-4$ & \multirow[t]{2}{*}{1.48} & \multirow[t]{2}{*}{1.07} & \multirow[t]{2}{*}{1.89} & \multirow[t]{2}{*}{$<0.001^{*}$} \\
\hline & Post & $3.06(0.10)$ & $0-4$ & & & & \\
\hline \multirow{2}{*}{$\begin{array}{l}\text { 26- I would be confident to explain the differences between therapeutic } \\
\text { cloning and reproductive cloning. }\end{array}$} & Pre & $1.81(1.20)$ & $0-4$ & \multirow[t]{2}{*}{1.40} & \multirow[t]{2}{*}{0.96} & \multirow[t]{2}{*}{1.83} & \multirow[t]{2}{*}{$<0.001^{*}$} \\
\hline & Post & $3.21(0.82)$ & $0-4$ & & & & \\
\hline \multirow{2}{*}{$\begin{array}{l}\text { 27- I would be confident to discuss the mitochondrial replacement } \\
\text { therapy. }\end{array}$} & Pre & $1.83(1.19)$ & $0-4$ & \multirow[t]{2}{*}{1.69} & \multirow[t]{2}{*}{1.28} & \multirow[t]{2}{*}{2.10} & \multirow[t]{2}{*}{$<0.001^{*}$} \\
\hline & Post & $3.52(0.74)$ & $1-4$ & & & & \\
\hline \multirow[t]{2}{*}{ The total score of stem cell research } & Pre & $1.76(0.89)$ & & \multirow[t]{2}{*}{1.51} & \multirow[t]{2}{*}{1.20} & 1.82 & $<0.001 *$ \\
\hline & Post & $3.27(0.56)$ & & & & & \\
\hline The total knowledge score & Pre & $2.09(0.30)$ & & 1.00 & 0.86 & 1.15 & $<0.001 *$ \\
\hline & Post & $3.09(0.41)$ & & & & & \\
\hline
\end{tabular}

Abbreviations: $M=$ Mean; $S D=$ Standard Deviation; $M i n=$ Minimum score; Max = Maximum score; $C I=$ Confidence Interval; $M D=$

Mean Difference; Pre $=$ Pre-educational intervention; Post $=$ Post-educational intervention

* Significant at $p<0.05$ based on paired-samples t-test. 
$\dagger$ The code was reversed for the false or misleading statements to be "Four = Strongly Disagree" and "Zero = Strongly Agree".
Note: The total score of knowledge is the sum of the statements' scores for the four major domains (stem cell basic knowledge, potential applications, therapeutic uses, and research) for each participant divided by 27. 


\section{Table 4(on next page)}

Pre- and post-educational intervention mean attitude scores and differences $(n=48)$

Abbreviations: $M=$ Mean; $S D=$ Standard Deviation; $M i n=$ Minimum score; $M a x=$ Maximum score; $C l=$ Confidence Interval; $M D=$ Mean Difference; Pre $=$ Pre-educational intervention; Post $=$ Post-educational intervention

* Significant at $p<0.05$ based on paired-samples t-test.

Note: The total attitude score is the sum of the scores of the ten statements for each participant divided by ten. 
Table 4. Pre- and post-educational intervention mean attitude scores and differences $(n=48)$

\begin{tabular}{|c|c|c|c|c|c|c|c|}
\hline \multicolumn{4}{|c|}{ Pre- and post-educational intervention mean scores of students' attitudes regarding stem cells } & \multicolumn{4}{|c|}{$\begin{array}{l}\text { Differences between pre-and } \\
\text { post-educational interventions }\end{array}$} \\
\hline Statements & Score & $M(S D)$ & $\begin{array}{l}\text { Min- } \\
\text { Max }\end{array}$ & $M D$ & \multicolumn{2}{|c|}{$\begin{array}{c}95 \% \text { CI } \\
\text { Lower Upper }\end{array}$} & $p$-value \\
\hline $\begin{array}{l}\text { 1- I am interested in expanding my knowledge about stem cells } \\
\text { (positive). }\end{array}$ & Post & $3.77(0.43)$ & $3-4$ & 0.48 & 0.22 & 0.74 & $0.001 *$ \\
\hline \multirow{2}{*}{$\begin{array}{l}\text { 2- Stem cell education should be integrated into medical college } \\
\text { curricula (positive). }\end{array}$} & Pre & $2.83(0.10)$ & $0-4$ & \multirow[t]{2}{*}{0.52} & \multirow[t]{2}{*}{0.13} & \multirow[t]{2}{*}{0.91} & \multirow[t]{2}{*}{$0.010^{*}$} \\
\hline & Post & $3.35(0.93)$ & $0-4$ & & & & \\
\hline \multirow{2}{*}{$\begin{array}{l}\text { 4- I think stem cell therapies give rise to ethical controversies } \\
\text { (negative). }\end{array}$} & Pre & $1.29(1.09)$ & $0-4$ & \multirow[t]{2}{*}{-0.16} & \multirow[t]{2}{*}{-0.58} & \multirow[t]{2}{*}{0.25} & \multirow[t]{2}{*}{0.420} \\
\hline & Post & $1.13(1.20)$ & $0-4$ & & & & \\
\hline \multirow{2}{*}{$\begin{array}{l}\text { 5- I think stem cell therapies give rise to religious controversies } \\
\text { (negative). }\end{array}$} & Pre & $1.88(1.10)$ & $0-4$ & \multirow[t]{2}{*}{-0.75} & \multirow[t]{2}{*}{-1.23} & \multirow[t]{2}{*}{-0.27} & \multirow[t]{2}{*}{0.003} \\
\hline & Post & $1.13(1.30)$ & $0-4$ & & & & \\
\hline $\begin{array}{l}\text { 6- Government should spend money to support stem cell research } \\
\text { (positive). }\end{array}$ & Pre & $3.38(0.82)$ & $1-4$ & 0.31 & 0.01 & 0.62 & $0.046^{*}$ \\
\hline bank (positive). & Post & $3.10(1.23)$ & $0-4$ & & & & \\
\hline 9- People should consider the donation of their babies' umbilical cord & Pre & $2.85(0.10)$ & $0-4$ & 0.42 & 0.00 & 0.83 & $0.049 *$ \\
\hline blood for a public bank (positive). & Post & $3.27(1.13)$ & $0-4$ & & & & \\
\hline 10- I am willing to pay money for preserving the umbilical cord blood & Pre & $2.63(1.20)$ & $0-4$ & -0.28 & -0.82 & 0.27 & 0.322 \\
\hline $\begin{array}{l}\text { of my baby in a private bank for later use if a therapeutic need arises } \\
\text { (positive). }\end{array}$ & Post & $2.35(1.52)$ & $0-4$ & & & & \\
\hline The total attitude score & Pre & $2.66(0.56)$ & & 0.19 & 0.02 & 0.38 & $0.048 *$ \\
\hline & Post & $2.85(0.53)$ & & & & & \\
\hline
\end{tabular}

Abbreviations: $M=$ Mean; $S D=$ Standard Deviation; $M i n=$ Minimum score; Max = Maximum score; $C I=$ Confidence Interval; $M D=$

Mean Difference; Pre = Pre-educational intervention; Post $=$ Post-educational intervention

* Significant at $p<0.05$ based on paired-samples t-test.

Note: The total attitude score is the sum of the scores of the ten statements for each participant divided by ten. 


\section{Table 5 (on next page)}

Gender differences in mean knowledge and attitude scores pre-and post- educational intervention

Abbreviations: $M=$ Mean; $S D=$ Standard Deviation

* Significant at $p<0.05$ based on independent-samples t-test. 
1 Table 5. Gender differences in mean knowledge and attitude scores pre-and post- educational intervention

\begin{tabular}{|c|c|c|c|c|c|c|}
\hline \multirow[t]{2}{*}{ Score } & \multicolumn{3}{|c|}{$\begin{array}{l}\text { Pre-intervention differences between } \\
\text { males and females }(\mathrm{n}=48)\end{array}$} & \multicolumn{3}{|c|}{$\begin{array}{l}\text { Post-intervention differences between } \\
\text { males and females }(\mathrm{n}=48)\end{array}$} \\
\hline & \begin{tabular}{|c|} 
Males $(n=32)$ \\
$M(S D)$
\end{tabular} & $\begin{array}{c}\text { Females }(n=16) \\
M(S D)\end{array}$ & $p$-value & $\begin{array}{c}\text { Males }(n=32) \\
M(S D)\end{array}$ & $\begin{array}{c}\text { Females }(n=16) \\
M(S D)\end{array}$ & p-value \\
\hline Total score of stem cell basic knowledge & $2.15(0.32)$ & $2.12(0.24)$ & 0.734 & $3.15(0.45)$ & $2.99(0.49)$ & 0.279 \\
\hline Total score of stem cell potential applications & $2.85(0.66)$ & $2.28(0.85)$ & $0.014 *$ & $3.52(0.58)$ & $3.35(0.61)$ & 0.369 \\
\hline Total score of stem cell therapeutic uses & $1.82(0.65)$ & $1.89(0.59)$ & 0.719 & $2.50(0.86)$ & $2.35(0.68)$ & 0.571 \\
\hline Total score of stem cell research & $1.95(0.81)$ & $1.39(0.95)$ & $0.036^{*}$ & $3.30(0.62)$ & $3.20(0.41)$ & 0.588 \\
\hline Total knowledge score & $2.16(0.27)$ & $1.95(0.30)$ & $0.017 *$ & $3.14(0.42)$ & $3.00(0.39)$ & 0.267 \\
\hline Total Attitude score & $2.66(0.60)$ & $2.66(0.50)$ & 1.000 & $2.81(0.52)$ & $2.92(0.55)$ & 0.517 \\
\hline
\end{tabular}

Abbreviations: $M=$ Mean; $S D=$ Standard Deviation

* Significant at $p<0.05$ based on independent-samples t-test. 